\title{
Brivaracetam: review of its pharmacology and potential use as adjunctive therapy in patients with partial onset seizures [Corrigendum]
}

\author{
Mumoli L, Palleria C, Gasparini S, et al. Drug Des Devel \\ Ther. 2015;9:5719-5725.
}

On page 5722, in Table 1, the notes section is missing; it should read: Klein et al ${ }^{34}$ data presented as percent reduction in seizure frequency over placebo per 28 days.

On page 5722, left column, line 8, the sentence "The percent reduction over placebo in baseline-adjusted seizure frequency $/ 28$ days was $9.2 \%$ and $20.5 \%$ in the BRV 50 and $100 \mathrm{mg} / \mathrm{d}$ groups, respectively" should read "The percent reduction over placebo in baseline-adjusted seizure frequency $/ 28$ days was $10.2 \%, 9.2 \%$ and $20.5 \%$ in the BRV 20,50 and $100 \mathrm{mg} / \mathrm{d}$ groups, respectively".

On page 5722 , right column, line 9, the sentence "Responder rate was $21.6 \%$ for placebo group, $38.9 \%$ for BRV $100 \mathrm{mg} / \mathrm{d}$, and $37.8 \%$ for BRV $200 \mathrm{mg} / \mathrm{d}$; the percent reduction of partial onset seizures in 28-day frequency was $22.8 \%$ for BRV $100 \mathrm{mg}$ and $23.2 \%$ for BRV $200 \mathrm{mg}$ " should read "Responder rate was $21.6 \%$ for placebo group, $38.9 \%$ for BRV $100 \mathrm{mg} / \mathrm{d}$, and $37.8 \%$ for BRV $200 \mathrm{mg} / \mathrm{d}$; the percent reduction of partial onset seizures in 28-day frequency over placebo was $22.8 \%$ for BRV $100 \mathrm{mg}$ and $23.2 \%$ for BRV $200 \mathrm{mg}$ ".
On page 5723, left column, line 22, the sentence "Currently an open-label, multicenter, follow-up study to evaluate the long-term safety and efficacy of BRV is ongoing (BRITE study-NCT01339559)" should read "Currently four openlabel, multicenter, follow-up studies to evaluate the longterm safety and efficacy of BRV are ongoing: N01125 (NCT00175916), N01199 (NCT00150800), N01372 (NCT01728077), and N01379 - BRITE (NCT01339559)".

On page 5724, the first sentence of the Conclusion should read "BRV is a novel AED whose efficacy in partial epilepsies has been studied and established in six randomized controlled trials; ${ }^{30-35}$ furthermore, two recent meta-analyses have confirmed significant effects for BRV in patients with refractory partial seizures. ${ }^{29,43}$ ",

In the reference list, page 5725, reference 34 (Klein et al), the link should be: http://www.abstracts2view.com/aan/ view.php?nu=AAN15L1 S31.009, which links directly to the abstract text.

\section{Publish your work in this journal}

Drug Design, Development and Therapy is an international, peerreviewed open-access journal that spans the spectrum of drug design and development through to clinical applications. Clinical outcomes, patient safety, and programs for the development and effective, safe, and sustained use of medicines are a feature of the journal, which has also been accepted for indexing on PubMed Central. The manuscript management system is completely online and includes a very quick and fair peer-review system, which is all easy to use. Visit http://www.dovepress.com/testimonials.php to read real quotes from published authors. 